Available online at: $\mathrm{http}: / /$ proceeding.rsfpress.com/index.php/pss/index

LPPM UPN “Veteran” Yogyakarta Conference Series

Proceeding on Political and Social Science (PSS)

Volume 1 Number 1 (2020): 51-65

\title{
Misinformation and Disinformation of COVID-19 on Social Media in Indonesia
}

\author{
Senja Yustitia, Panji Dwi Asharianto \\ Universitas Pembangunan Nasional Veteran Yogyakarta \\ 1'E-mail address: senja.yustitia@upnyk.ac.id; E-mail address: panjidwi.pd@gmail.com
}

\begin{abstract}
Infodemics in the COVID-19 pandemic situation biases information, and the community's need for the correctness of information becomes increasingly difficult to fulfill. Misinformation and disinformation circulate widely on social media, including instant chat applications. The research problem's formulation is how the contents of COVID-19 misinformation and disinformation that occurred on social media in Indonesia for the period January 20 - March 9, 2020. The research method used is quantitative with a content analysis approach. All misinformation and disinformation cases on social media are taken from cases that have been fact-checked by Mafindo (Indonesian AntiDefamation Society) in a predetermined period. In total, there were 69 cases of misinformation and disinformation. As a result, there are three main conclusions in this study. First, false context and misleading content are the most common types of misinformation and disinformation. Second, the producers and distributors of these messages are individuals with Facebook and WhatsApp. Third, these findings indicate a tendency for the production and distribution of misinformation and disinformation messages to be carried out by individuals. The high accessibility of the community facilitates this to communication media.
\end{abstract}

Keywords: infodemics, misinformation, disinformation, COVID-19, social media

\section{INTRODUCTION}

The Covid-19 pandemic has an impact on every sector of life. Apart from the public health and economic sectors, it is also interesting to see how people talk about social media. It is crucial; because information can change people's perspectives, including influencing how the government conducts community policies.

The massive pandemic accompanies by a high intensity of discussion about this on social media. The conversation is about what and how this virus develops and is contagious and not true. Even the WHO (World Health Organization) mentions the trend of infodemics (Hao and Basu, 2020). In general, infodemic is a condition that refers to an abundance of 
information, but some are accurate, and some are not. These circumstances make it difficult for people to find reliable sources and guides (PAHO, 2020). For this problem, WHO Director-General Tedros Adhanom Ghebreyesus even stated that now WHO is not only fighting against pandemics but also infodemics (Zarocostas, 2020). Syvie Briand, Senior Director of Infectious Hazard Management, said that a lot of misinformation was circulating in the community due to the tsunami of information in the community (Zarocostas, 2020).

Infodemics makes information biased, and people's need for the correctness of information becomes increasingly difficult. COVID-19 is a new virus, which has resulted in a large number of fatalities and its spread across continents. This condition should not be exacerbated by the existence of biased and questionable information.

To combat infodemics, WHO staff builds intensive relationships with digital media and social media to combat misinformation on health. For example, in August 2020, WHO collaborated with Pinterest to link accurate information about vaccines (Ritchtel, 2020). WHO, through its Instagram account @who also posted several facts to straighten out the misinformation that has been developing around COVID-19.

The spread of an infodemic is also thought to impact and can trigger violence and divide communities. For example, Indonesia joined 12 other countries in the Cross-Regional Statement on Infodemic in the Context of Covid-19 on 12 June 2020. Indonesia, represented by the Indonesian Minister of Foreign Affairs Retno L.P. Marsudi, said that this effort marked a severe attempt to prioritize facts and avoid misperceptions of information (Kemenlu, 2020).

In Indonesia, long before the COVID-19 pandemic, health themes were not a subject that was free from misinformation and disinformation. Data from the Indonesian Journalists Association (PWI) in 2017 states that the most widely spread hoax is health information (Fanani, 2017). Health hoax's emergence also requires health literacy to be more serious (Prasanti, 2018).

In Indonesia, when government authorities officially announced this virus in Wuhan, Hubei China, information about this has become a hot topic on social media. The public has also consumed news from unconfirmed sources through various information channels. It is proved that Mafindo (Indonesian Anti-Defamation Society) has carried out fact-checking activities since January 29, 2020, until now.

Based on this background, this research focus on how misinformation and disinformation occurred in Indonesia from January 20 through March 9, 2020. This period was chosen because, on January 20, 2020, the health authorities in Wuhan, Hubei, China, announced three people Wuhan who died due to pneumonia, the impact of coronavirus. In Indonesia, President Joko Widodo announced that two people in Indonesia have tested positive for COVID-19. March 9 is one week after the president gives an official statement. Thus, the research can see how the contents of misinformation and disinformation that have occurred on social media since the virus was first discovered in Hubei China until it hit Indonesia. 


\section{LITERATURE REVIEW}

\section{II.1. Infodemics}

Infodemics are too much information, some accurate and some not, making it difficult for people to find reliable sources and guides when they need them. According to the UN, infodemics spans four major thematic areas where people look for trustworthy information and rumors; the cause and origin of the virus and disease; its symptoms and transmission patterns; and available treatments. Prophylactics and cures; and the effectiveness and impact of interventions by health authorities or other institutions (WHO, 2020).

Based on various discussions and thoughts, the United Nations then formed four frameworks to guide the government and society. First, interventions and messages must be based on science and evidence. Second, knowledge about COVID-19 must be translated into messages that can be acted upon, change behavior, presented in the right way, and accessed by all society elements. Third, governments must reach out to key communities to better understand their concerns, and information needs to tailor suggestions and messages to address issues. Fourth, strategic partnerships must be formed with social media and technology platforms and stakeholders and academia, and civil society (WHO, 2020).

There are several good reasons to answer why infodemics hurt and make the pandemic situation worse. First, infodemics make it difficult for people to make decisions and find reliable sources. Second, it makes people feel anxious, depressed, emotionally drained. Third, it can influence the decision-making process, especially for fast decisions needed. Fourth, there is no control over the quality of what is published, and people who read it use this information as a basis for decision making. Fifth, anyone can write it on their social media or personal channels (PAHO, 2020).

\section{II.2. Misinformation And Disinformation}

Misinformation is false or inaccurate information intentionally intended to deceive (factsheet). According to Liang Wu et al., misinformation and disinformation refer to incorrect or faulty information. The main difference between the two lies in the intention, whether the information is intentionally created to deceive or not. Disinformation usually refers to intentional cases, while misinformation is accidental (Wu et al., 2019).

Kai Shu et al. mentioned that misinformation is part of fake news. Fake news is news that is deliberately created and proven to be fake. Apart from satire, rumors, conspiracy theories, hoaxes, and misinformation are included as part of fake news. What distinguishes misinformation from others is that it is made consciously as false news (Shu et al., 2017).

In this study, the types of misinformation and disinformation used to refer to the definition developed by the First Draft, adapted by Mafindo (Indonesian Anti-Fitnah Society). According to the First Draft (Wardle, 2017), there are seven types, mis, and disinformation as in the picture below; 


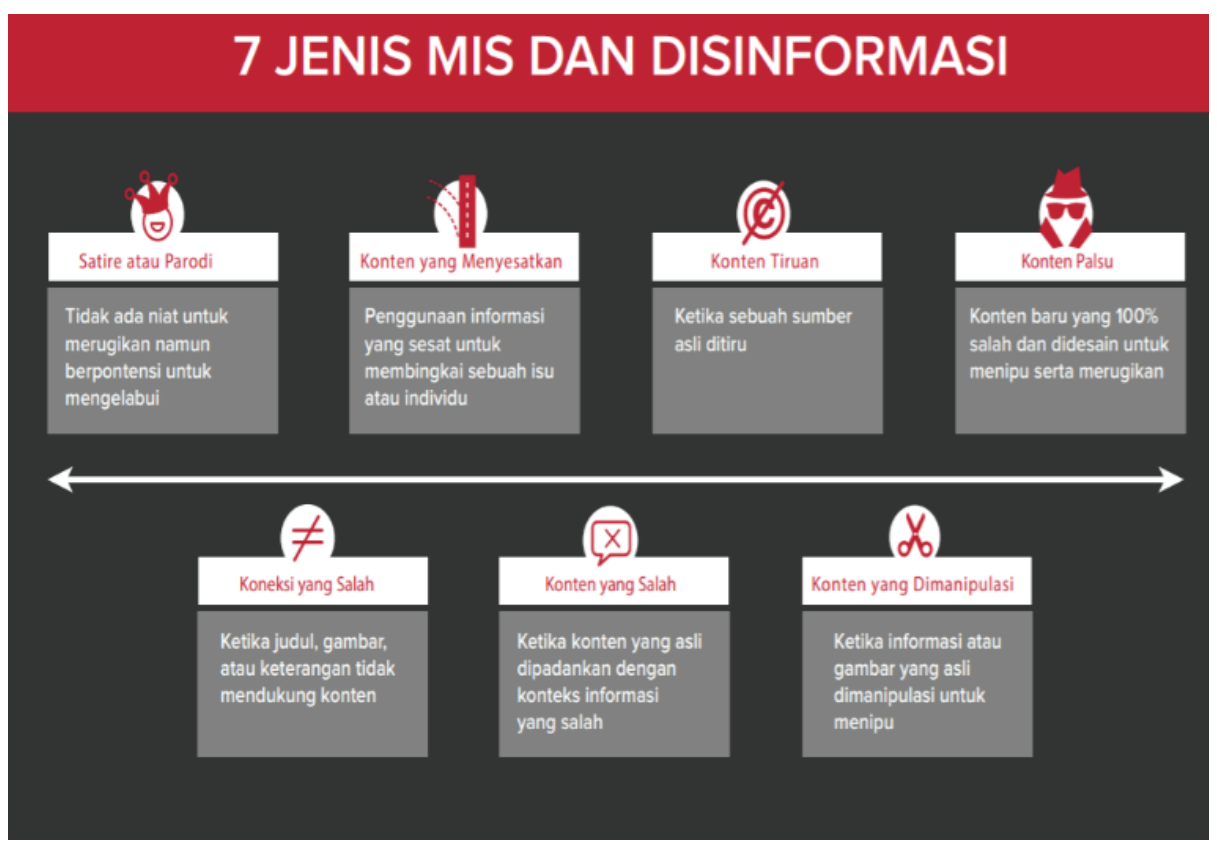

Figure 1. 7 Types of Mis and Disinformation

Source: First Draft

In a pandemic context, misinformation is very diverse but generally refers to information that does not refer to facts and correct data. That is why when COVID-19 began to become a pandemic, the Department of Medicine, the Division of Infectious Disease and Immunology UMASS Medical School gave an open attitude containing a statement of solidarity with medical personnel because of misinformation that this outbreak was part of a conspiracy theory. According to them, conspiracy theories create fear and prejudice that endanger global collaboration in the fight against COVID-19 (Calisher et al., 2020).

\section{RESEARCH METHODOLOGY}

Quantitative content analysis has different characteristics and research steps from other quantitative research. Content analysis research steps are to determine the concept, what to see, and research. After that, the researchers decided on the technique. Processes and procedures in measuring the concept that you want to see empirically (operationalization). This concept is derived into units that can be seen and observed empirically (Eriyanto, 2011).

All misinformation cases and disinformation on social media and instant chat applications come from data that has been fact-checked by Mafindo for a predetermined period. In total, there were 69 cases of misinformation and disinformation. The case is researched using the analysis unit and the categories, as shown in table 1. 
Tabel 1. Analysis Unit and Categorisation

\begin{tabular}{|c|c|c|}
\hline No & Categorization & Analysis Unit \\
\hline \multirow[t]{6}{*}{1} & \multirow{6}{*}{$\begin{array}{l}\text { The media for spread } \\
\text { misinformation } \\
\text { disinformation }\end{array}$} & FB \\
\hline & & Twitter \\
\hline & & Whatsapp \\
\hline & & Website \\
\hline & & Youtube \\
\hline & & Lain-lain \\
\hline \multirow[t]{7}{*}{2} & \multirow{7}{*}{$\begin{array}{lr}\text { Types } & \text { of } \\
\text { misinformation } & \text { and } \\
\text { disinformation } & \end{array}$} & Satire/ parody \\
\hline & & Misleading content \\
\hline & & Imposter content \\
\hline & & Fabricated content \\
\hline & & False connection \\
\hline & & False context \\
\hline & & Manipulated content \\
\hline \multirow[t]{5}{*}{3} & \multirow{5}{*}{$\begin{array}{l}\text { Misinformation and } \\
\text { disinformation themes }\end{array}$} & Politics \\
\hline & & Health \\
\hline & & Religion \\
\hline & & Combined \\
\hline & & Other \\
\hline \multirow[t]{15}{*}{4} & \multirow{15}{*}{$\begin{array}{l}\text { Objects that are the } \\
\text { target of misinformation } \\
\text { and disinformation }\end{array}$} & President Joko Widodo \\
\hline & & Ministry of Health \\
\hline & & $\begin{array}{l}\text { Other ministries (apart from the ministry of } \\
\text { health) }\end{array}$ \\
\hline & & Governor \\
\hline & & Mayor \\
\hline & & Influencer \\
\hline & & Political figures \\
\hline & & Health institutions in provinces and districts \\
\hline & & Health laboratory \\
\hline & & Islamic religious leaders \\
\hline & & Non-Islamic religious leaders \\
\hline & & Health workers \\
\hline & & Spoke person \\
\hline & & Gugus Tugas Penanganan COVID-19 \\
\hline & & Other \\
\hline \multirow[t]{4}{*}{5} & \multirow{4}{*}{$\begin{array}{l}\text { Countries mention on } \\
\text { misinformation and } \\
\text { disinformation material }\end{array}$} & China/ Tiongkok \\
\hline & & Indonesia \\
\hline & & Amerika \\
\hline & & Other \\
\hline \multirow[t]{3}{*}{6} & \multirow{3}{*}{$\begin{array}{lr}\text { Spreader } & \text { of } \\
\text { misinformation } & \text { and } \\
\text { disinformation } & \end{array}$} & Individual \\
\hline & & Non-individual (insitution/ comunity) \\
\hline & & Other \\
\hline
\end{tabular}




\begin{tabular}{|l|l|l|}
\hline 7 & Content of the post & Image \\
\cline { 3 - 3 } & & Text \\
\cline { 3 - 3 } & & Other \\
\hline 8 & Sources of & News web \\
& $\begin{array}{l}\text { misinformation and } \\
\text { disinformation content }\end{array}$ & Social media \\
& & Personal opinion \\
& & Opinion figures \\
& & Mainstream media \\
& & Instant Message \\
& Other \\
\hline
\end{tabular}

The resulting quantitative data were analyzed by looking at the frequency distribution generated by relating to findings that were manifest in misinformation and disinformation texts.

\section{FINDING AND DISCUSSION}

The content analysis carried out on 69 cases of misinformation and disinformation for 20 January - 9 March 2020 shows an interesting trend. The period chosen by the researchers was the time when COVID-19 was first known to cause 3 Wuhan people to die until finally, President Joko Widodo announced that 2 Indonesians had also contracted the same virus. The cases studied were messages of misinformation and disinformation in the early days of the Indonesian people hearing and knowing COVID-19.

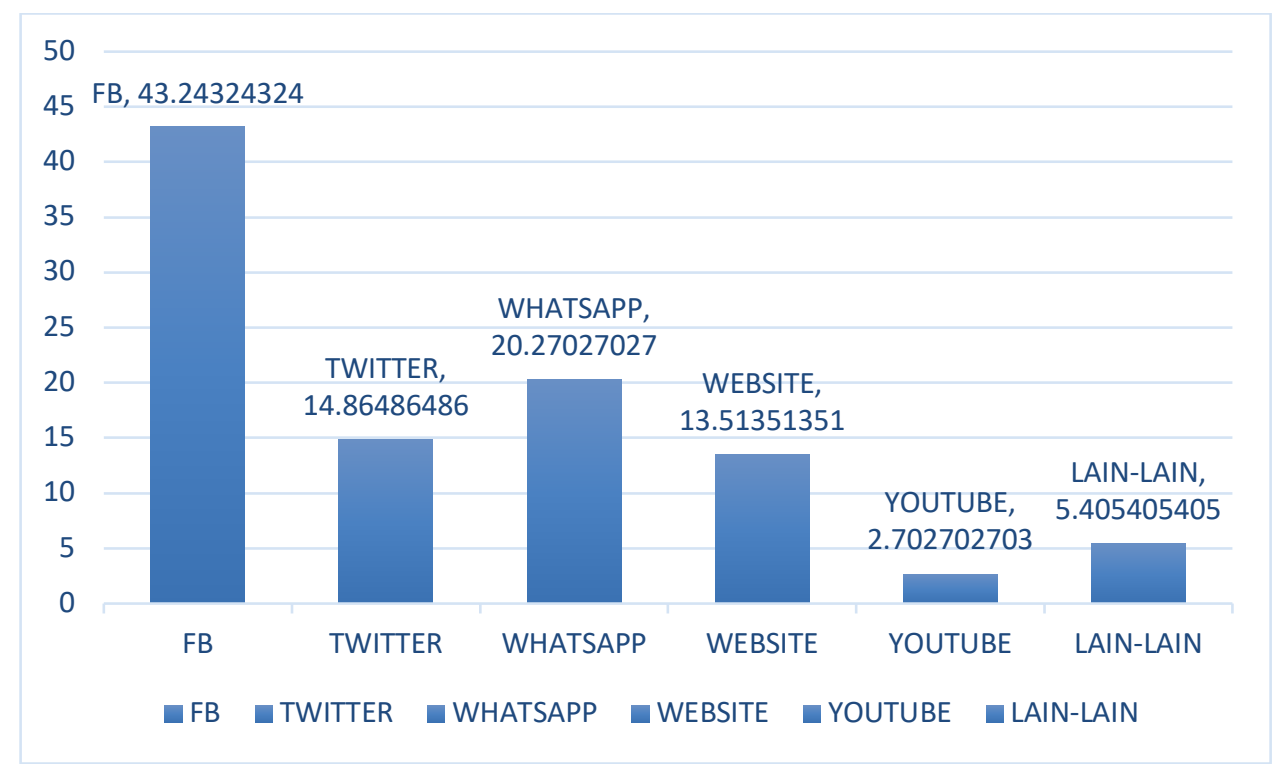

Figure 2. Media for the Spread of Misinformation and Disinformation 
Figure 2 shows that Facebook (FB) became the most massive media for spreading in the early period of the emergence of COVID-19. Although not directly related, this is in line with the CIGI-Ipsos Global Survey's findings on Internet and Security Trust 2019, which states that 2 out of $3(67 \%)$ of the world's people agree the most significant hoax spread is on Facebook (Jayani, 2019). Still, in the same report, it was stated that in Indonesia, 84\% of respondents said they had found fake news on Facebook (Jayani, 2019). These data strengthen the data of this study's findings in the media analysis unit for the dissemination of misinformation and disinformation.

WhatsApp and Twitter are the next platforms used to spread misinformation and disinformation. The three platforms in the most widely used position are indeed media with technology that are easier to operate by ordinary people. In Indonesia, the most commonly used social media platforms are Youtube, WhatsApp, Facebook, Instagram, and Twitter (Jayani, 2020). In this COVID-19 theme, Youtube is not user-friendly because its complexity makes it more challenging to produce and distribute.

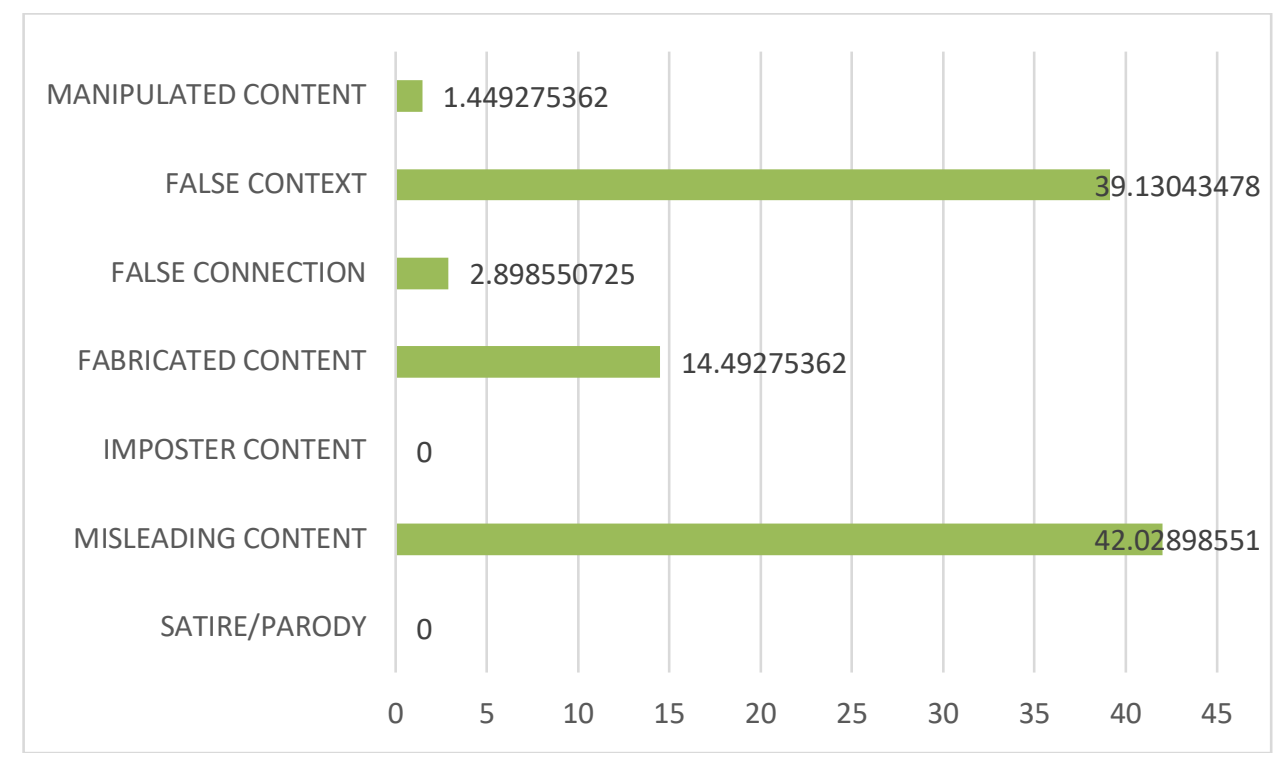

Figure 3. Types of Misinformation and Disinformation

In the analysis unit on misinformation and disinformation, the two types of messages mostly produced regarding COVID-19 are misleading content and false context. False contexts are correct information but conveyed in the wrong context (Wardle, 2017).

Misleading content is the use of information to frame a particular issue or individual (Wardle, 2017). For example, there is news that the Pirbright Institute owns a coronavirus patent. The virus patent mentioned is IBV M41, intended to prevent acute respiratory disease spread in birds, especially farmed ones. This post is from V.A Shiva Ayyadurai, who is a US Republican Party politician. As of January 27, 2020, the post had 540 responses, 146 comments, and 296 shares (Khairil, 2020). Content that is misleading and directly related to 
the Indonesian government, for example, in a message from the Ministry of Health about preventing the corona influenza virus by keeping the throat moist. This post, made on January 26, 2020, by the FB Culinary Order account. The content is not in line with the Ministry of Health's official recommendation regarding a healthy lifestyle.

Misleading content is straightforward to produce and can be trusted by audiences because it usually uses a pattern by reproving certain people or institutions. It causes the news to circulate as if it were valid because it was "validated" by a trusted party both in terms of competence (marked by an academic degree) and authority (for example, position).

Meanwhile, the false context example is news about a Malaysian girl who died from COVID-19. A video accompanies the post on Jasmine Dede Humaira's FB account. The video showing a woman falling inside the shop is true, but the cause of death was not the coronavirus. The post-dated January 27, 2020, was only inserted with a short narrative showing that the coronavirus had arrived at Shah Alam Selangor, Malaysia.

Another false context is about a video with a narrative about the coronavirus in China that can make people shudder for Friday prayers. The video, shared through the FB account on January 15, 2020, has circulated in 2018. The two cases above have the same characteristics; the events in the video are events that happened but were conveyed in the wrong context.

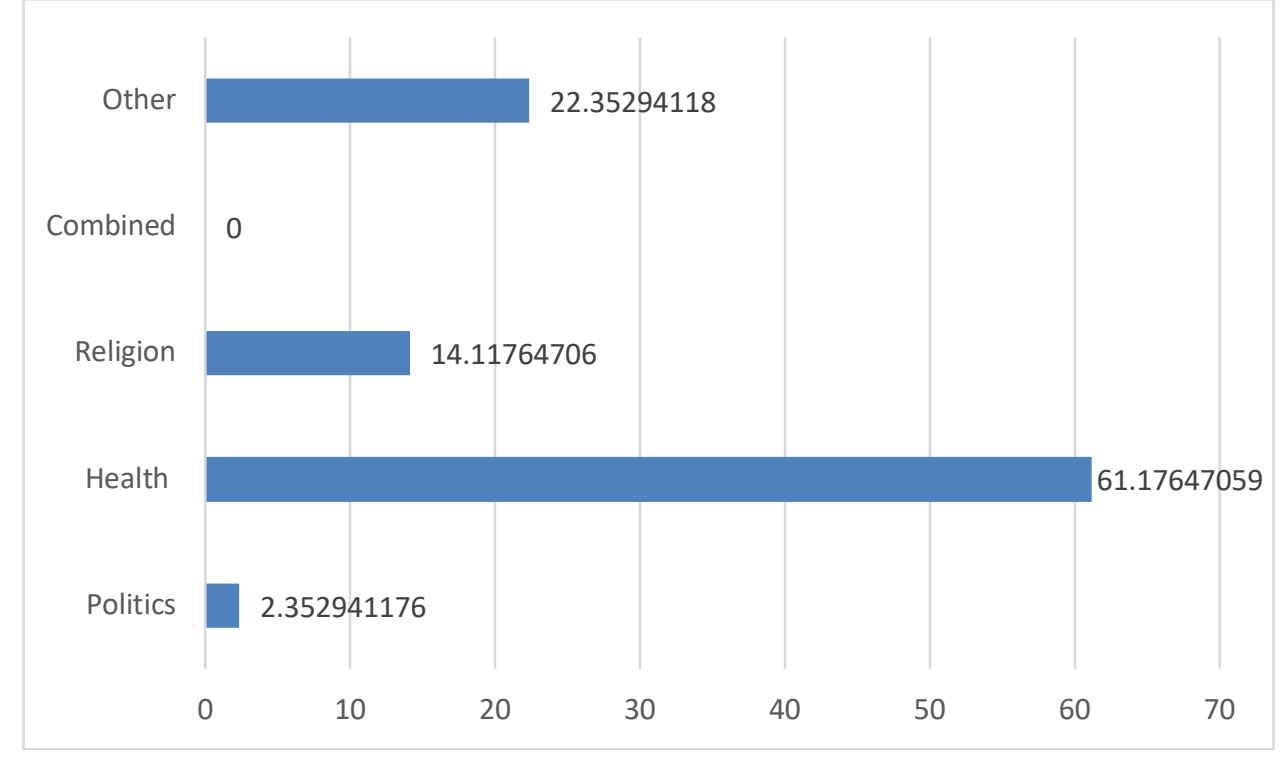

Figure 4. Misinformation and Disinformation Themes

Figure 4 shows that health is the theme most discussed in the misinformation and disinformation of COVID-19. A very new virus, unheard of before but its victims quite a lot, making speculation about COVID-19 relatively high. The significant impact of the emergence of COVID-19 is health, so health themes dominated at the beginning of the outbreak of this virus. Usually, the misinformation and disinformation that arise are related to the means of healing. For example, the discovery of vaccines, drugs, or living behaviors 
can prevent people from contracting the coronavirus. One example is a chain message on WhatsApp, which says the coronavirus can spread through the eye.

Other misinformation and disinformation health themes are related to victims. Messages like this, apart from causing fear, are also full of sensation aspects. With minimal knowledge and lack of information about COVID-19, sensational statements are more interesting than ordinary ones.

Meanwhile, the theme of religion is predominantly related to Muslims. It is nothing new because Anti / Pro-China sentiment has always been associated with Muslims. This condition also occurs in the misinformation and disinformation of COVID-19.

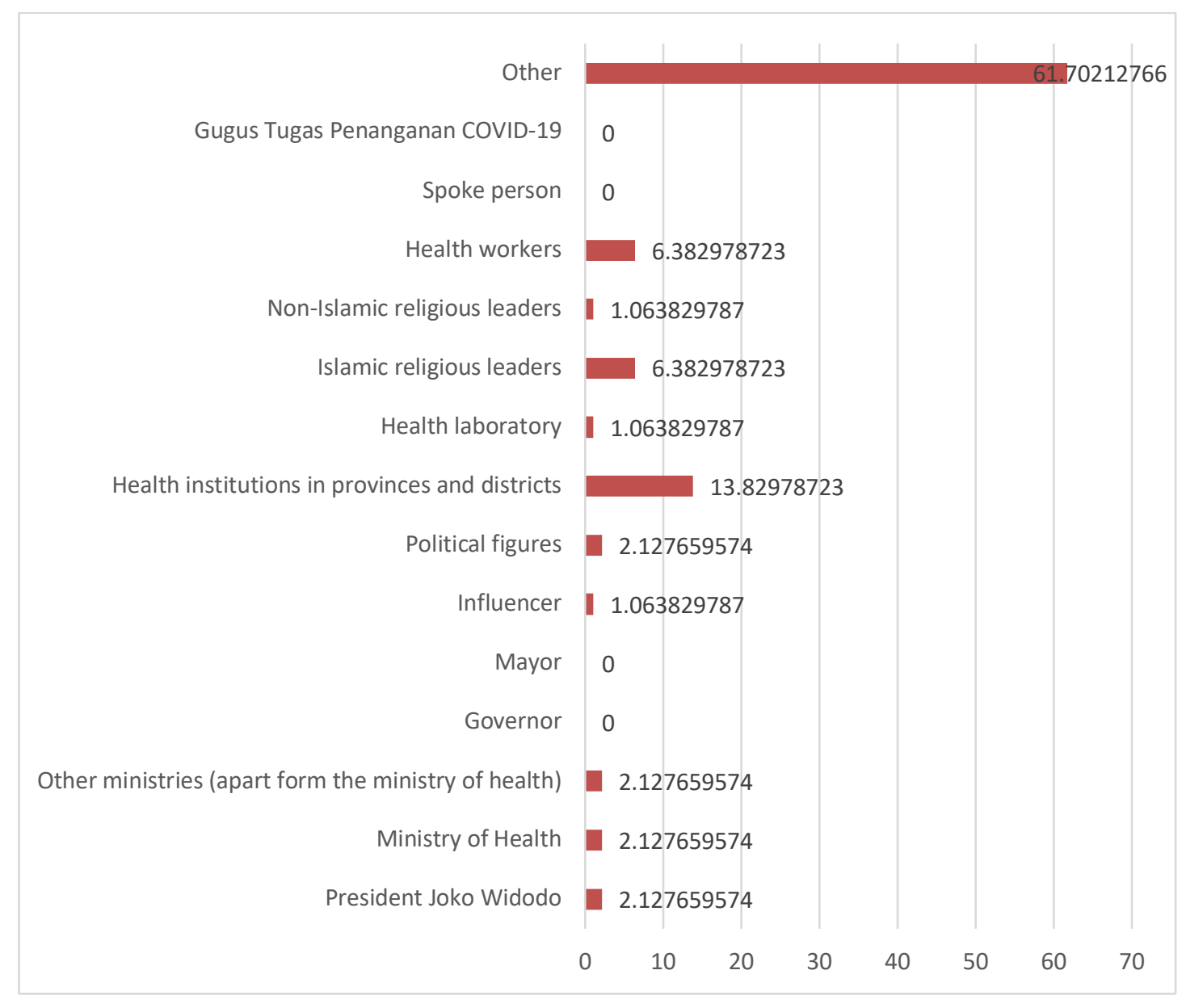

Figure 5. Objects to which Misinformation and Disinformation is Subject

In the early period of the COVID-19 pandemic, the objects that were the target of misinformation and disinformation were still very random and had not focused on certain parties. Moreover, at that time, Indonesia's central government, including the relevant ministries, had not provided many statements and guidance regarding the pandemic. On the other hand, there is still a lot of information in circulation related to conditions abroad, such 
as coming from the source country of the outbreak, namely China. Meanwhile, related to Indonesia's conditions is information about community outbreaks in several areas such as Makassar, Palangka Raya, Indramayu, Yogyakarta, and Depok. Besides that, it is also a place related to areas where migrants can enter and exit, such as airports. That is why, in figure 5, health institutions in the province and district and health workers get a high percentage.

Meanwhile, there are also cases of misinformation associated with Islam. For example, there is a post on Facebook saying that the coronavirus has been mentioned for a long time in Iqro's book. Iqro is a Quran reading method that has been on record since the early 1990s in Indonesia. This book was created by K.H As'ad Human.

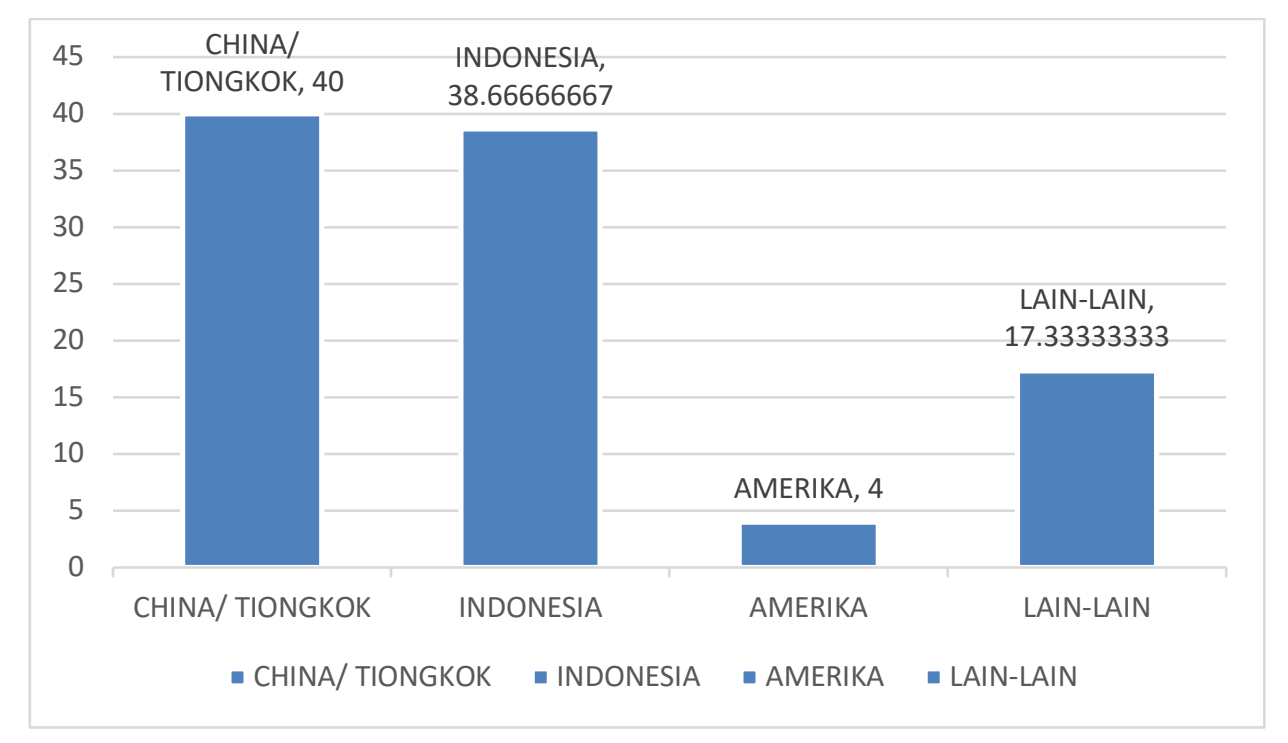

Figure 6. Countries Mention on Misinformation and Disinformation Material

In the unit of analysis shown in figure 6, Indonesia and China are the countries most discussed in misinformation and disinformation material. It is quite logical considering that apart from Indonesia being the central location for this research to be conducted, in that period, President Joko Widodo said that Indonesia had not encountered any COVID-19 sufferers. Meanwhile, apart from being the country of origin for the virus, China is often associated with particular religious sentiments on other issues. 


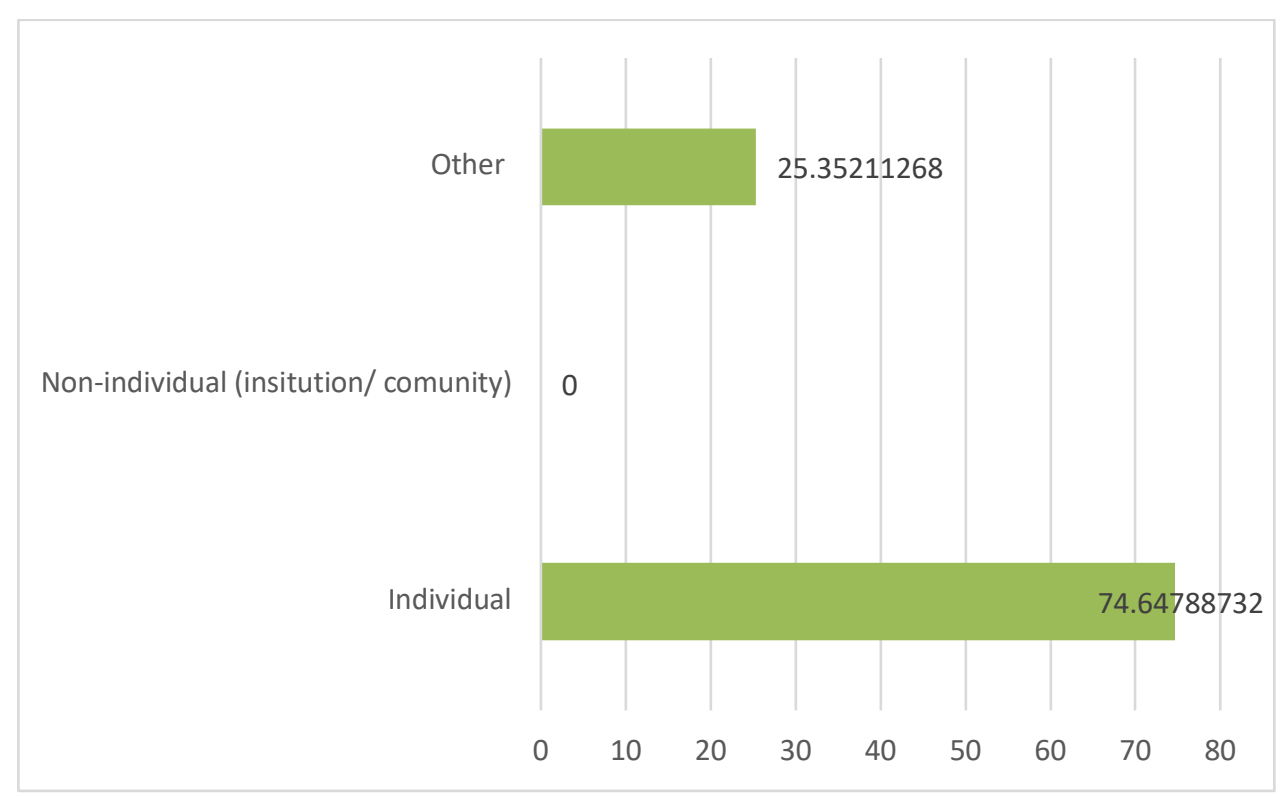

Figure 7. Spreader of Misinformation and Disinformation

It is easy to produce and distribute messages, making individuals spread the messages that are misinformation and disinformation the most. Although COVID-19 is an issue related to the world of health, with high accessibility to the media, everyone can be a source of information. Increased accessibility to media coupled with low literacy and lax regulations allows anyone to be anonymous to produce messages that people are likely to believe. In line with infodemics' main problem, the high intensity of messages with low-quality information, message consumers' main difficulty is in the sorting process. It is related to whether the information is correct and can be accounted for or vice versa.

It is interesting to see the misinformation and disinformation from the side of the actor. In this study, actors cannot be shown very clearly because the nature of social media itself can obscure the identity of the source of the message. However, the researchers saw that in some cases, the misinformation and disinformation sources were people who generally had a large number of followers on social media platforms. High engagement makes messages spread more quickly. Also, public figures make the message is considered competent even though the message content is not by the quality of its expertise. It happens when misinformation about the thermal gun can damage the brain. This information was conveyed by political observer Ichsanuddin Noorsy in a video clip of an interview with Helmy Yahya on Youtube. The case shows that popularity makes the reach of this message broad and that public trust is high. 


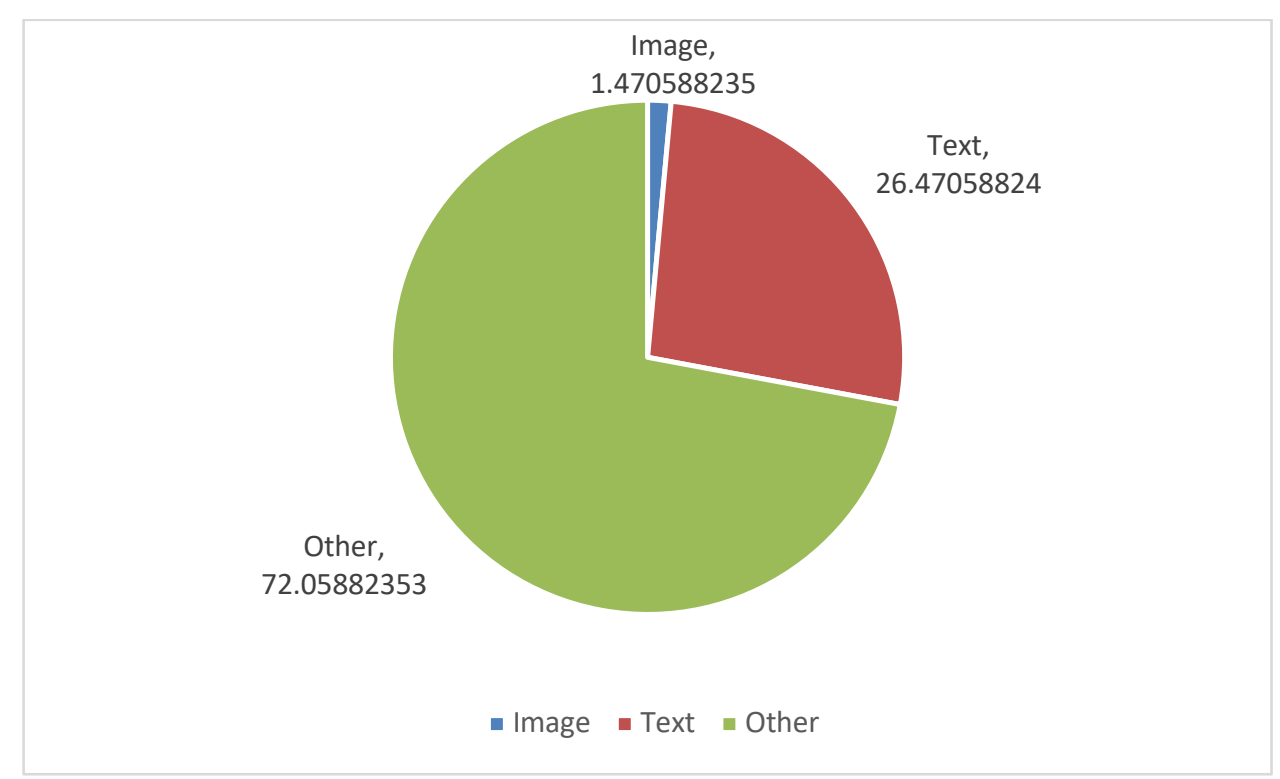

Figure 8. Content of the post

Complex messages, such as pictures and writing, tend to be more trusted by people as accurate information. Also, the presence of images will make other people more sure of the contents of the message. This trend also occurred in misinformation cases and disinformation for January 20 - March 9, 2020. The content of posts on social media is dominated by combining pictures and writing. As communication technology advances, the content of such posts remains easy to create and distribute.

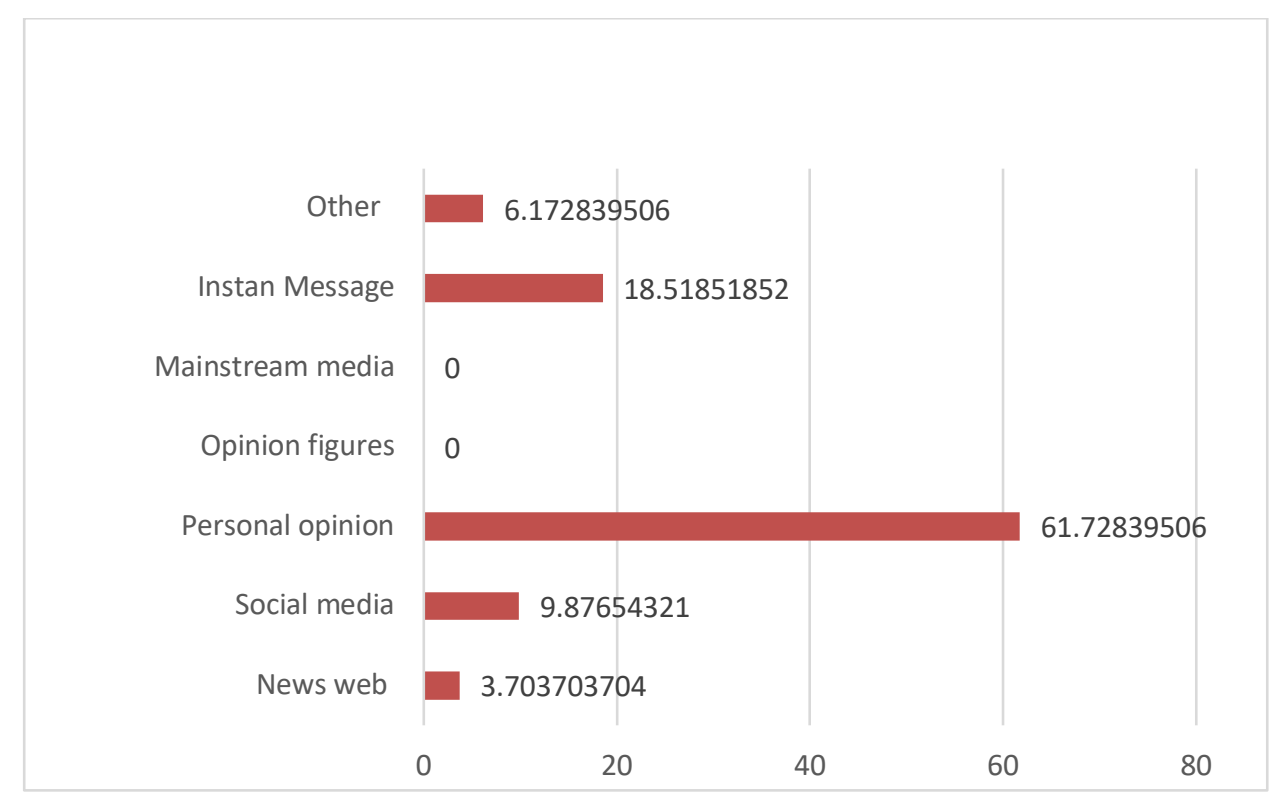

Figure 9. Sources of Misinformation and Disinformation Content 
Figure 9 is closely related to the data in Figure 7. The ease of production and distribution of messages made the source of most misinformation and disinformation during this period personal. Meanwhile, in the second position comes from instant messages whose primary source is unknown. Low digital literacy makes these two things a predictable risk. In this period, the mainstream media did not become a source of misinformation and disinformation due to media routines that required official sources and demanded high accuracy. When COVID-19 has not spread throughout the country, there are not many sources that can be extracted. Media that does not have a contributor in China rely entirely on official news agency sources, so misinformation and disinformation can be easily eliminated.

The source of misinformation and disinformation from social media is also related to the findings in figure 2 regarding the distribution media, which places Facebook and Twitter in a fairly high percentage. These findings also show a very close relationship between individuals who have access to communication media, the choice of social media users, and sources of misinformation and disinformation.

\section{CONCLUSION AND FURTHER RESEARCH}

The There are three main conclusions in this study. First, false context and misleading contents are the most common misinformation and disinformation from January 20 to March 9, 2020. Second, the message producers and distributors are individuals with Facebook and WhatsApp. Third, these findings indicate a tendency for the production and distribution of misinformation and disinformation messages to be personal. Anyone can do, share, and modify the message. The high accessibility of the community facilitates this to communication media.

This research's limitation lies in its rules in seeing who the actors who spread misinformation and disinformation. It is due to the nature of social media, which can facilitate anonymous message sources. Also, the nature of content analysis research produces manifest data that can be seen in the text. Seeing that the potential for infodemics is still enormous, this research is very open to development. By comparing these data for the next period, the tendency of the contents of misinformation and disinformation can be mapped more comprehensively.

\section{REFERENCES}

Calisher, C. et al. (2020) Statement in support of the scientists, public health professionals, and medical professionals of China combatting COVID-19, The Lancet. Elsevier Ltd. DOI: 10.1016/S0140-6736(20)30418-9.

Eriyanto (2011) Analisi Isi Pengantar Metodologi untuk Penelitian Ilmu Komunikasi dan Ilmu-ilmu Sosial Lainnya. Jakarta: Kencana Prenada Media.

Fanani, A. K. (2017) Survei menyebutkan hoax terbanyak soal info kesehatan, Antaranews. Available at: https://www.antaranews.com/berita/626813/survei-menyebutkan-hoaxterbanyak-soal-info-kesehatan (Accessed: 9 September 2020).

Hao, K. and Basu, T. (2020) The coronavirus is the first true social-media 'infodemic', MIT Technology Review. Available at: https://www.technologyreview.com/s/615184/thecoronavirus-is-the-first-true-social-media-infodemic/ (Accessed: 15 April 2020).

Jayani, D. H. (2019) Survei CIGI: Facebook, Medsos yang Banyak Digunakan untuk 
Menyebar Hoaks, Databoks. Available https://databoks.katadata.co.id/datapublish/2019/06/14/survei-cigi-facebook-medsosyang-banyak-digunakan-untuk-menyebar-hoaks (Accessed: 14 September 2020).

Jayani, D. H. (2020) 10 Media Sosial yang Paling Sering Digunakan di Indonesia, Databoks. Available at: https://databoks.katadata.co.id/datapublish/2020/02/26/10-media-sosialyang-paling-sering-digunakan-di-indonesia (Accessed: 15 September 2020).

Kemenlu (2020) INDONESIA BERSAMA 12 NEGARA PRAKARSAI PERNYATAAN BERSAMA DI PBB TENTANG “INFODEMIC ”, Kementrian Luar Negeri RI. Available at:https://kemlu.go.id/newyork-un/id/news/7101/indonesia-bersama-12-negara-

prakarsai-pernyataan-bersama-di-pbb-tentang-infodemic (Accessed: 9 September 2020).

Khairil, M. (2020) [SALAH] Coronavirus Memiliki Paten, Turnbackhoax. Available at: https://turnbackhoax.id/2020/01/29/salah-coronavirus-memiliki-paten/ (Accessed: 15 September 2020).

PAHO (2020) Understanding the Infodemic and Misinformation in the fight against COVID19 What is the Infodemic?

Prasanti, D. (2018) 'Health Information of Literation as Prevention Processes of Hoax Information in the Use of Traditional Medicine in Digital Era (Literasi Informasi Kesehatan sebagai Upaya Pencegahan Informasi Hoax dalam Penggunaan Obat Tradisional di Era Digital)', Journal Pekommas, 3(1), p. 45. doi: 10.30818/jpkm.2018.2030105.

Ritchtel, M. (2020) W.H.O. Fights a Pandemic Besides Coronavirus: An 'Infodemic', NYTimes. Available at: https://www.nytimes.com/2020/02/06/health/coronavirusmisinformation-social-media.html (Accessed: 9 September 2020).

Shu, K. et al. (2017) 'Fake News Detection on Social Media', ACM SIGKDD Explorations Newsletter, 19(1), pp. 22-36. DOI: 10.1145/3137597.3137600.

Wardle, C. (2017) Fake news. It's complicated., First Draft. Available at: https://firstdraftnews.org/latest/fake-news-complicated/ (Accessed: 14 April 2020).

WHO (2020) Coronavirus Disease 2019 (COVID-19), WHO. DOI: $10.1213 /$ xaa.0000000000001218.

$\mathrm{Wu}$, L. et al. (2019) 'Misinformation in social media: Definition, manipulation, and detection', ACM SIGKDD Explorations Newsletter, 21(2), pp. 80-90. Available at: https://www.public.asu.edu/ huanliu/papers/Misinformation_LiangWu2019.pdf.

Zarocostas, J. (2020) 'How to fight an infodemic', Lancet (Lond̄on, England). Elsevier Ltd, 395(10225), p. 676. DOI: 10.1016/S0140-6736(20)30461-X. 
